\title{
The sense, landscape and image. How the tourist destination is replicated in postmodernist times
}

\author{
Maximiliano E. Korstanje*
}

University of Palermo

\begin{abstract}
Policy makers, practitioners and analysts have focused on the psychology to induce consumers to new products. These new eye-catching packaging products in tourism and hospitality industries and beyond are commercialized to thousands of home thanks to the media. We are living in times, digital times where organic image plays a pivotal role in arousing emotions and experiences, although these experiences were not authentic. Following this discussion, initialized some time ago by D. Maccannell and other sociologists, the present paper explores the philosophical roots of image to expand the current understanding about our ocular-centrism. At time, tourists select a destination, they are moved by "the wish of majority", but once destination is maturated, its attractiveness declines. What seems to be interesting to discuss here is the connection between perceived safety (risk) and attraction (organic image). Following I. Kant's contributions, we present a conceptual model to understand how the dilemma of safety leads consumers to visual pollution.
\end{abstract}

Key Words: Tourist Destination, Organic Image, Visual Image, Safety, Visual Pollution.

\section{Introduction}

Tourist destinations are resulted by the combination of diverse elements and factors, geology that formed the psychical boundaries of landscapes during hundred million years as well as socio-structural which refers to the culture and customs of locals. Certainly, over decades scholars have developed a new concept linked to sustainable paradigm that attempts to study the connection of human beings with their environs (Farrell and Runyan, 1991; Baloglu and Mcclearly, 1999; Jollife, 2005; Cordero Ulate, 2006; Roberts and Tribe, 2008; Quinn, 2009; Ryan, Huimin and Chon, 2010; Ambrosie, 2010). The precautionary principle, as explained by Jafari, focused on the negative effects of tourism such as pollution and other types of contamination. As any other industry, tourism should be regulated balancing the interests of all involving stakeholders, even the local population. Ecology is a key aspect of governance and economic prosperity in the developing countries (Dinica, 2009).

The neologism, visual pollution, bespeaks us to the degree of unattractiveness given to certain landscape or vista because of human intervention. Tourists and visitors face a bad experience of those sites which has a visual pollution. Therefore, many scholars have vested their interests to explore the fields of sustainability where topics like this fall (Flad, 1997; Eyenga et al, 2009). The present essay review, rather, is aimed at examining the contribution of philosophy to expand the current understanding of tourist-gaze and risk. The thesis is that although visual pollution exerts negative consequences for international destinations, there is a point where the lack of visual elements in the setting, as the case of deserts, causes fear-mongering effects. Based on Kant's legacy, it is first-

* Departments of Economics University of Palermo. E-mail: mkorst@palermo.edu 
rate of importance to reconsider the role of gaze in the configuration of safety, first and almost in tourist safety. This philosophical text not only interrogates about the flaws tourism-related research is today but invites to reflections respecting to the role played by perceived safety in tourist destinations. If we pay the necessary attention, we will see how risk not only triggers the tourist travel but also its return. Korstanje and Olsen (2011) explored the dark roots of horror movies in US finding interesting outcomes. First and foremost, tourists go beyond the urban boundaries because of evasion and other recreational goals. Although their personal security would be compromised, tourists need knowing new dispersed places to feel an atmosphere of novelty and adventure. Secondly, travellers and tourists select rare and risky destinations as deserts or hills, if something bad occurs, no police support is given. The degree of attractiveness they feel becomes in a double-edged sword when they are attacked by psychopaths (as the films Hostel, The Texas Chainsaw Massacre or The hills have eyes). As George, Poyyamoli and Inbakaran (2010) put it, tourism seems to rest on two contrasting psychological drives, novelty and protection. Touring are based not only in the needs of displacement and avoidance, but also in returning to home. While the tourist motivation, this means the curiosity to transcend the own culture, predominates, travellers manifest their wish in visiting places and exotic destinations, but if this drive is reduced, the "nativistic motivation" will lead tourist to home. This motivation allows the reduction of uncertainty to tolerable levels for mind.

\section{Conceptual debate}

The light and darkness have been historically concepts that concerned the Greek philosophers. From the Plato's metaphor of Cavern on, image has been referred by abundant literature in philosophy and humanities. Blumenberg (1993) is correct when says, the supremacy of vision, that engendered the modern sightseeing, has been resulted from frames introduced by industrial revolution where text and picture monopolized the figure of truth. The vision-centric tendency not only set the pace to interesting entertainment cultures, but also to the Science. The concept of experimentation was based on the needs to see previously the evolution of studied phenomenon. The obsession of West for aesthetic, derived from ancient Greece, has been accelerated producing an ocular-centrism where the eye has more credibility than other senses. The hegemony of vision cuts the world in two, authenticity and falsehood. (Levin, 1993; Blumenberg, 1993).

From the seminal works of the anthropologist Edward Hall, who argued that people connection was determined by the physical distance respecting to other people, social scientist was fascinated by the covert code of communication; E. Hall considered that certain silent stereotypes that confers a message to recipients. By means of a new technique, the proxemic one would understand the process of communication from an all encompassing manner (Hall, 1958). It would be not surprising to see although tourist destination may be visually polluted involving negative effects for tourists, who should decide to withdraw or abandon the site, the attractiveness of a destination is certainly determined by the equilibrium between space and vision. If we are correct, this would explain the reasons why some groups travel to certain destinations, which are left behind once saturated by other groups. Some examples as Mar del Plata, created as tourist destination from 50s decade and matured during the successive years (Khatchikian, 2000 ;Troncoso \& Lois, 2001; Pastoriza, 2011), validates this previous assumption. Gradually some groups were being replaced by other newer that opted for Mar Del Plata copying the higher-class consumption patterns. Which psychological factors intervene in this issue?

Santos has explained convincingly that tourism moves by means of spatial models. These cognitive models give meaning to spaces by the imposition of negotiated stereotypes. Tourism, in this vein, is inextricably intertwined to the concept of territory (Santos, 2007; FernandezFuster, 1985; Leiper, 1979; Palhares, 2002). Tourists go from a geographical starting point (source) by means of a way to a final destination. During this displacement the role of tourist may be or not active (Pearce, 2003). The usual ordinary sense of home may be projected by many images, pictures and allegories that help other travellers who never had been there how the place is. Although this process wakes up some questions along with the question of authenticity (Maccannell, 2003;2007; Urry and Larsen, 2012), one should not loose the sight that images, souvenirs and pictures are emotionally situated to express memorable experiences (Peters, 2011).

All these factors are combined to give tourists a sense of satisfaction depending on its early drives (Crompton, 1979; Pasuraman, Zeithaml \& Berry, 1988; Carman, 1990; Fornell, 
1992; Kotler, Haider \& Rein, 1994; Moraes, 2007; Nadeau at al, 2008). Nonetheless, others scholars have criticized this viewpoint to be seen very superfluous, based exclusively in marketing purposes that nothing have to do with scientific observations. Spreng \& Mackoy (1996) alerted that cognitive and perceptual factors play a secondary role in the tourist destination loyalty. Perception may be less important to determine the destination attractiveness than we imagine. What is necessary to discuss here is that the perception is not conditioned by external induced drives as the program one watch on TV, but by entangled emotions which are internally formed in the self. According to this, consumers select the perceptual stimuli that are in agreement with its internal emotional background. These flaws found in the specialized literature are a product of an old idea coined in the Lancaster School that focuses on the person as a rational homo-economicous. Per this view, persons are moved by the accumulation of desires and arousals which once satisfied are cyclically repeated (Nisbett and Kanousse, 1969). The sensation-related research interrogates about the inception of consumption, and of course its relation to perception. To some extent, sensation and selection have triggered countless doubts in the social sciences. Theory of threshold admits that there exists a bottom line where things are caught or rejected. Since each person adopts diverse adjustments to expand or reduce this threshold, the experience and sensation may follow heterogeneous dynamics. Every person has developed perceptual frameworks respecting to the external objects (Celma \& Du Bois, 1999). Rather, Hussain and Ekiz (2007) demonstrated that emotional factors are more important at time of selecting a destination than perceptual. Travellers are led to buy certain product moved by tangible assets, which may be visually observed. These results were validated by other studies as Marzo et al (2002) conducted in a hotel chain in Spain. Marzo and colleagues realized how tangible characteristics of products exert considerable influence in the consumer decision making process. To understand this, one might speculate there is a clear correlation between service perception and perceived quality. The tangible assets are often identified to involuntarily and deep-seated emotions inside the person. The experience that associates these drives to external stimuli plays an important role to stable images for the mind. This would be the reason why we remind those events, which are being captivated by our eyes in lieu of other senses (Tamagni, Lombardo, \&
Gazzerra, 2000; Gazerra and Lombardo, 2007). Image for some reason is of paramount importance to draw the tourist-experience. Convincingly, Woodside and Dubelaar (2002) describe how image-induced efforts are not enough to forge a tourist destination in consumer mind. Decisions are made following thoughts and past experiences. Sometimes, secondary but important factors during the trip determine the experience.

Some studies evidenced a connection between tourism, environs and psychology. The consumption may be encouraged following criteria associated to safety, empathy, certainty or perception. Any destination has an imaginary, an image, a tale which replicates the cultural values of societies to next generations. To what extent this imaginary is authentic or a product for being consumed by touring, is one of the most fascinating aspects of social research today (Mansfield, Korstanje and Busby, 2011). In perspective, there is consensus in point out that destination image is organically designed by the market, but publicized by diverse mechanisms as literacy and novels (Mansfield, 2008; Mansfield, Korstanje and Busby, 2011), movies (O'Connor, Flanagan and Gilbert, 2010), postcards (Andriotis and Mavric, 2013), souvenirs and brochures (Molina and Agueda, 2005), mouth to mouth experiences and others. It is safe to say while image may be individually interpreted, its socialization follows an archetype which is standardized and cloned to a broader public (Korstanje, 2012).

Gregory Ulmer said that travels (tourism) and science are inextricably intertwined. The image seems to be the results of the convergence between experience and sightseeing. Paragraphing to Solon's travels, it is hypothesized by Ulmer that first theories in ancient Greece were validated because of their experience beyond the boundaries of the town. The fictional information is being combined to factual experience. That way, first theorists were indeed tourists to the extent their displacement were determined by curiosity alone. The perceptual system of a society is based on an allegory which not always may be validated, and for that, give reason to the social scaffolding (mythology). Tourism, by the discovery of landscapes, draws the myths society needs (Ulmer, 1994)

Travelling beyond the boundaries of home, abroad, presupposes a dislocation. Although, images and visual marketing pivot the connection between self, narrative and destination, it is clear, as the investigation of Araujo Perazzolo, Capellano Dos Santos and Pereira (2013) show, other psychological drives are involved in the 
same process. Certainly, tourists should develop an attachment to certain territory, which may be real or imagined-one. This rite of passages is moved by the desire of welcome that is still enrooted in the principle of hospitality. If this principle must be ensured, whatever the reason may be, traveller adopts a nativist attitude. It is possible that globalization paves the ways for the acceleration of travels, but this may engender conflict and despair.

Castrogiovanni (2007) is not wrong when relates tourism to a rite of passage based on a linguistic re-introduction. Tourist space is something else than a geographical space, because it defies the logic principle. Tourist space works in a dialogical nature nuancing opposed values such as good, bad, order, disorder, high and low. The conceptual dichotomies are redeemed according to a narrative which is politically built. Tourism engenders an objective-subjective re-structuration that appeals to a much broader hierarchal order. Touring can be considered a political practice where domination and legitimacy converge. The communication allows the construction and interpretation of a site which is symbolically negotiated. Not surprisingly, any site is enrooted in a process of communication that gives to it certain sense. Castrogiovanni anyway does not delve into the evolutionary nature of meaning and image. As stated, some elites may withdraw from their holiday destination simply when other peripheral groups invade its symbolized spaces of leisure. However, may we define what is a landscape?.

Gilbert Ryle, a couple of decades back, wrote "a foreigner visiting Oxford or Cambridge for the first time is shown a number of colleges, libraries, playing fields, museums, scientific departments, and administrative offices. He then asks but where is the University?. I have seen where the member of the Colleges lives, where the Registrar works, where the scientists experiment and the rest. But I have not yet seen the University in which reside and work the members of your University"..."the University is just the way in which all that he has already seen is organized. When they are seen and when their coordination is understood, the University has been seen" (Ryle, 1949: p. 17-18). This example clearly evidences how a landscape works. Historically, we would have educated to think that Cartesian dissociation between body and mind but this is a wrong view of the situation. Like a landscape, mind corresponds with an abstract but powerful concepts whose dynamic may be not observed unless by means of the overall functioning.
The French legacy has been critique respecting to the obsession by aesthetics that characterizes the modern world. P. Bourdieu alerts that our love for photography fulfils certain psychological needs such as protection, fear of time passing, communication, evasion, and status. Photography would serve as a mediator to reduce the sentiment of anxiety that generates the passing of time, this means the fear of death. Nevertheless, Bourdieu adds, if one pays attention to the connection between photography and classes, it is not surprising to see that image (picture) replaced the place of social bond. His main thesis is that those professional skilled classes that show serious emotional problems in their relatives or friends take more pictures than other blue-collar worker classes. The level of richness disarticulates the social bond to the extent this gap should be filled by secondary mediators, photography, alcohol and drugs are part of a large list. Once the modernity has radically altered the tradition and styles of life, the obsession for image and aesthetics has surfaced (Bourdieu, 2003).

\section{The mediated landscapes}

Image and death are inextricably intertwined. Hans Belting explains convincingly that ancient tribes crafted a mask of the king once died, which were present in all rites and even in times of war. The reason was very simple, the presence of king were evoked in order for the monarchy to gain further legitimacy and acceptance in times of turbulence. From that moment onwards, human beings always have recurred to create allegories of their experiences. From this archaic tendency, Belting adds, resulted the arts, painting and anything which is related to visual industries. Archaeological evidences suggest that tombs are the last barrier between death and life. This serves as a prophylactic door that protects humans from the spirits coming from the hereafter. Death for all cultures signifies a real disaster that must be controlled so that the society does not disintegrate. In view of this, images of dead accompanied the funeral rites until the industrial revolution (Belting, 2007). Most certainly, in digital times death has been denied, rejected and forgotten. As a result of this, images are virtually created and stored in nowhere, at devices or machine-like boxes. Phillipes Aries (2011) put the paradox of modernity under the lens of scrutiny. While in ancient times people accepted and lived with the idea of death, cemeteries were constructed beyond the 
city walls. At the time, death is being denied and civilizations devote times and efforts to expand the life, cemeteries are being introduced in the core of industrial cities. Processing and accelerating the image seems to be part the secularization of culture, once humankind denied the hereafter. The culture of emulation, in terms of Belting, set the pace to culture of simulacra. While any emulation consists in copying in present time anything from an original in a new copy-cat, simulacra is enrooted in the future. Simulacra do not exist in reality.

Mearleau-Ponty indicates any man is unable to keep unaware about death with the exception if he is reduced to the animal-state. His consciousness of death is the last ontological limits with the world. This experience brings us close to others, who like us may die. Since the other becomes in an object for my consciousness, like a piece of the world as I perceive it, each self looks the death of others to live avoiding the anxiety of nothingness (Merleau-Ponty, 1964, p 68). To put this in brutally, we create images of our sensorial outside world to exorcise death, in so doing, picturesque reminds the past to reprocess our being this world in the present. G. H Mead alerted about the strange fascination for consuming bad news. Since nobody knows its accurate time of dying, he argued, the self enjoys in the other-deaths because this entails my own safety (Mead, 1999).

As the previous argument given, it is clear how from its inception, TV and visual technology has advanced so far and fast as never before. Its control and hegemony over thousand millions homes worldwide not only is complete but a point of discussion widely expanded in anthropology fields. TV and the media would be used as an instrument of education, or a mechanism of alienation. William F. Baker and George Dessart (1998) in their book down the tube explained that TV becomes today a deceptive but efficient instrument in democratic societies to know further about the news and events which otherwise remain closed to the public. To what extent, these news are not fabricated or negotiated according to private economic interests seems to be the point to study. Television and Broadcasting have not evolved in the same way in US and UK. While in the former the market monopolized the control of air by means of advertising, the latter created the BBC (British Broadcasting Corporation) to regulate the content. Since BBC was not a corporate private organization, but an organization directly controlled by government, the commercial interests were restricted to the public wellbeing. As a result of this, British tele- vision and media, until Tatcher deregulation, were aimed at broadcasting pluralistic and heterogeneous voices on air. Over years, journalism has debated into two conceptual models at time of covering news. Surely, in democratic societies the libertarian model develops the lineage of Enlightment identifying the rights of citizenry to get the correct information and the true. But if libertarian model is unable to provide standardized rules of quality and regulation, the private business corporations form a trusteeship model. This argument is validated by Budd, Craig and Steinman in other interesting piece, consuming environments. American researcher found interesting correlation between fear, violence and TV. Although they acknowledge that TV does not insufflate these sentiments in the public opinion directly, the fact is that the commercial cultures are creating mediated environments tailored to the desire of society. The possession desire that changed the world from XIXth century has mobilized a gaze in which some moments commoditized, printed to be consumed. The culture of spectacle has accelerated the explosion of advertisements in TV reframing the reality in a pseudo-setting. Last but not least, the French philosopher Jean Baudrillard insisted in the idea that postmodernism is an irreversible force, in weberian terms, which engenders nonevents. Following the movie, Minority Reports, where a couple of precogs envisaged the future to mobilize police in pre-crime arrests, modernity and visual-led culture presents news that are enrooted in the future, and for that never existed in reality. Following this, the Media and TV leads audience from simulation to simulacra (Baudrillard, 1998). To break the nature of the media, we have come back to desert, which represents the real.

Following Virilio's argument, the conceptual bridge between what is real and the world of fiction arises from our capacity to understand the being of others in this world, their interests, hopes and of course frustrations. An experience of this nature places people together even though they stand geographically dispersed. However, the mediated reality works as a fictional depiction that generates a counter effect in which the heterogeneity of meaning is substantially minimized. The information is processed and framed under a mega-complex where the subjectivity of the people involved in the news event is reduced to a new form of mass consumption. In consequence, information overload creates a progressive sentiment of loneliness that leads people towards sadness, reclusion and despair (Virilio, 2007). It is important not to lose sight of the 
fact that international tourism revitalizes the ancient colonial violence that characterized the 19th century. Isolated resorts and Club Meds appear like fortresses in a desert. Symbolically, Virilio refers to the desert as a state of emotional desolation. As in the previous argument, tourism becomes a hegemonic instrument to create financial dependence and submission from the periphery to the center. The ancient value of civilization rooted in the citizen's ability to write is being replaced by the ability to travel. Travel therefore draws the boundaries between civilization and barbarity. Modern mass tourism is feasible precisely because travelers are not eager to discover new cultures and traditions but on the contrary merely seek to tour the known boundaries of Empire. Today, travel begins with a movie, a picture or a visual-driven image. The excess of velocity is often accompanied by a syndrome of inferiority where ordinary people realize the impossibility of controlling their own destiny. Anguish in the face of uncertainty is exploited by those in power through the technique of ideology. Of all aspects of life that make a person most afraid, death is the more frightful because it is uncontrollable (Virilio, 1996). In our times, modern, the reality set the pace to hyper-reality. Everything happens in a future but modifying the present. Like the American movie, minority report where precogs determined previously who would be arrested even before committing the crime, the modernity has eroded the social foundations of our societies. We live in a world that is nothing more than a techno-creation, simulation of reality. In this vein, the intensity of images Baudrillard adds, matches the degree of its denial. We may see for example, the American cinema. Baudrillard alerts this new industry, like tourism, is instrument of the imperialism to expand the Americanization to the world. Movies not only bespeaks of American values, but annihilated the real spirit of the cinema. The technical perfection for tuning a great image, spectacular, special and attractive, jeopardizes the understanding of history. What today we know of tragic events as Auschwitz, or Hiroshima depends on the movies. Nobody opens a book of history to read further. We have loose forever our connection with pasttime (Baudrillard, 2002).

\section{The sense of security and Sublime space in Kant}

At time of writing this manuscript, one of the most troubling challenges is the idea to bring the complexity of Kant to tourism fields. Kant is, even for philosophers, a brilliant exponent of encyclopaedic philosophy whose argument seems not to easy to digest. To put his development in a comprehensible way is a hard-task to accomplish. Therefore, it is important to delve into early writings of Kant (as on the beautiful and the sublime) to have an overview of what he later explained with accuracy around the axioms of perception in his book, the Critique of Pure reason.

Although Kant has written abundant material respecting to the relation between space and time, or perception, his book On the Beautiful and the Sublime, represents a master-work in the theme. Kant dissociates the beautiful from sublime. While the former exhibits what one may interpret from an external object, the latter hold an "air of mystery" that remains beyond the human control. For example, if we consider that a Greek sculpture is beautiful, this is because we can control the object with our gaze. Rather, a desert remains as a sublime spectacle, which cause fear but at the same time admiration. The sublime is always enrooted in our faculty of reason. An absolute sense of freedom is -frightful like the idea of slavery. Of course, sensibility takes a personal view according to the way each one perceives and internalizes the surrounding world. Kant admits that what is beauty to our mind wakes up a sentiment of happiness, but sublime alternates enjoyment with terror. Even if in both sense emotions are suitable at a first time, the consequent evolution derives in different forms (Kant, 2007, p. 10).

The sublime may manifest in three subtypes, terrible sublime, noble and magnificent. Vast deserts, or those landscapes isolated from the urban cities causes an extreme fear because we imagine tales and legends about monsters, or other entities that may put us in danger. If we see a beauty object as controllable, the sublime overwhelms us. Sublime remains large while beautiful small and decorated. "A very great height is sublime as well as very great depth, but the latter is accompanied by a sense of terror, the former by admiration. Hence the one may be terrible sublime, the other noble". (Kant, p. 11).

As the previous argument given, Kant continues, establishing a dialectic relation between his theory of sublime and beautiful and human temperaments. The values and its ways of thinking the sublime not only correspond to geographical points or landscapes, but to our social daily life. Convinced of this, Kant develops a 
theory of international affairs giving to Italians and French the status of beautiful whilst Germans keep sublime. He knows that temperaments are not pure construes; they are mixed to other components. Based on the obsession to reconstruct an all encompassing theory of beautiness, Kant recurs to aesthetic syllogisms to explain the universality of his observations. Far away of being a commodity, the nature (and the sentiment of beautiful and sublime) is imagined by the mind, and only is present there. Following this, the landscape would be the negotiated image of nature, we, the human beings, construct to make our life tolerable, or at least predictable. Of course, ones may scare to see the falls, while others may experience excessive attraction. Whatever the case may be, this begs an interesting question, why some places are attractive for ones and disgusting for others?

In the pure reason, Kant (2007) establishes that axioms of intuition encompass the beliefs. If we believe that things are simply because they are perceived by mind, how may we describe the schizophrenia or any hallucination?. The system of principle of pure understanding is based on three axioms, which are independent but connected in the mind. Experience is governed by a supreme principle of analytics and synthetic judgment, but this principle may be very well subject to simple contradiction. For that, Kant stipulates that the synthesis of representations rests on imagination. First, an object can be given a priori but I am not sure that would be real. Two images, as schizophrenic, may be seen at the same time and space, but only one is palpable. The self recurs to analogy to test what is the fake and real image. I can ask to a third person if he/she sees what I see, if not, the image turns down, but if the response is affirmative, the image is real. That way, although Kant recognizes things are individually modelled in mind, there are universal laws that take human off from nihilism and relativism. The discussion between authenticity and stage-authenticity, although Kant does not put in these terms, is enrooted in the history of humankind.

Unearthed from the cold and complex world of philosophers, we will see in this essay-review how Kant today has much to say respecting to the customer loyalty and tourist-destination image. Next, the "paradox of visual pollution", a neologism coined by us in early papers not only will be explained with detail but also placed under the lens of scrutiny. Josiah Royce recognizes in Kant, more than a genius, who never travelled beyond the boundaries of Konigsberg.
His legacy not only sheds light on the question of apperception, but attempted to resolve the problem of self-conscience and outside. If any existence is accompanied with others, also we are unable to escape from the moral law. Our sense of experience is shaped by what we do not know, what gives us as unfamiliar. We therefore perceive the world, as we are according to our inner-life. Undoubtedly, Kant marks the starting-point in the passage from medieval to modern philosophy, illuminating the ways of new more critique philosophers (the existentialists) (Royce, 1983)

\section{The paradox of visual pollution.}

We, humans, are prone to live with others in cities, because of safety and security issues. This suggests a dynamic determined by concentration of people, devices, goods and technology. Urban cities are places where lives thousand millions citizens in certain proximity but paradoxically in psychological isolation. The degree of depersonalization accompanied the decline of social bonds, which characterizes the modern life, has transformed the way of communicating. The excitement as well as expression of emotions seems to be circumscribed to private space. The work force in the urban context is framed under strict rules of competition and specialization that generates psychological dysfunctions. The alienatory nature of cities has been studied by Adorno and Marcuse who envisaged the advance of instrumentalism as the first and most prominent instrument of control and depersonalization. Mass-consumerism represents the most vivid and efficient form of controlling the critical thought deterring the inter-class struggle. Under a democratic façade, Marcuse adds, our regime is so totalitarian as others because an elite dictates that happiness and values may be bought only if we are free to do it. This biased image of democracy only is conducive to the liberalization of desires which are rechanneled towards the market-place. By the introduction of technologies, the ongoing creation of new elaborated products leads workers to work more to keep on buying (Marcuse, 1964). Of course, one realizes Marcuse's prophecies not only made reality but also the capitalist city has been divided in two opposite worlds, the labour and leisure, the norm and evasion. Year by year, thousand of travellers go out home to enjoy from their holidays, after a period of hard work, exams or other social pressures. The paradigms of sustainable tourism 
has focused on the negative effects of tourist concentration generates for the environment. In this vein, the works of Swarbrooke (2000), Capacci (2003), and Zuloaga (2006) may be suggested. Visual pollution is in its infancy but interesting research has been conducted in this field (Sampaio-Cioce et al, 2007).

To promote a tourist-destination at a first state, for example, a beach, policy makers turn their attention to invest money and time in convincingly advertising that captivates a broader audience. Once the image of this destination is consolidated, mouth to mouth recommendation makes the rest. The effects of visual contamination are based on a paradox. While the tourists are captivated by landscapes, or experiences, the destination is targeted over others. People travel following the existent infrastructure that facilitates amenities like at home, emulating their own style of life. No less true is that, with some exception, people attract more people. Tourists prioritize mass and urban destinations moved by two significant ideas. The first is the support that anyone may give in case of robbery or attack, secondly people are prone to think that if a good is mass-consumed; this is because it is fine. The founding parents of psychology and sociology realized the power and influence imitation does exert in human relations. Attitudinal dispositions are situated to what the majority thinks. To avoid the psychological isolation, people see and copy the attitudes of others only when they are shared by in-group (Noelle-Neumann, 1995). As noted above, we perceive a chaotic world in an ordered way, only because this brings us security. Lay-people need from majorities to reduce their sentiment of uncertainty, but at the same time, this creates discomfort, evasion and alienation. Without the majorities we will experience a sublime terror like the protagonists we have examined jointly to D Olsen (Korstanje \& Olsen, 2011). What is important to debate, is that our sense of safety is determined by biased and fabricated beliefs that not always are real. For example, we can abandon a sparsely-populated attractive feeling we are at risk but we can expose hours to sun simply because everybody do it. To put this in brutally, tourists gather themselves looking for stable cognitions ignoring the contrasting visual elements that contrast with their previous expectances. The order as it has been portrayed by mind selects those elements which remain incongruent. As Kant put it, we see beautiful a landscape that seems to be controlled by our gaze, while escape from those places when become sublime.
The negative visual assets of tourist-destinations, specialists attempt to adjust, are a result of our psychological cognitive system. Depending on the context, tourists agglomerate looking for a sense of security that never exists. The sense of security is given by the trust in others. Undoubtedly, the paradox is that this leads to visual pollution, when the destination receives further visitors than due. Last but not least, the visual pollution as a concept should be placed in contrasting opposition to a sublime destination but it is important to remind that both phenomena are inextricably linked.

\section{Conclusion}

As a mediator, organic image works reducing the degree of uncertainty and distrust brought by modernity. The present review unearthed the legacy of Kant to postulate the paradox of visual pollution. To expand the current understand as to how image is constructed, the following relevant points are explained.

- People feel safer when follow the mandate of majority.

- People fright to be rejected by the in-group.

- Tourism is based on two contrasting psychological drives, novelty and return to home.

- Tourists look for stable cognitions ignoring the real risks. For example, we may attend to a mass-beach for hours to sunbath ignoring skin-cancer risk-factors.

- A landscape is seen as beautiful when it may be controlled by gaze. Rather, the sublime not only inspires terror but also rejection.

- The quandary of security leads to visual pollution, which (unless otherwise resolved) creates discomfort and alienation.

The present essay review not only shed light on the problems of visual pollution and organic image, but also paves the ways for new doubts and questions in urban studies. Supporting Virilio's concern, one might speculate that the collective psychosis that engendered by the excess of image, is portrayed by the media to silence the criticism. This process sustains a chain of consumption that commoditizers people in products, citizens in consumers, persons in objects. In a world governed by images and aesthetics, which would be the role played by tourism?. 


\section{References}

Ambrosie, L.

2010 "Tourism Enterprises and Sustainable Development: international perspectives on responses to the sustainability agenda". Tourism Management. 31(6): 961-962

Andriotis, K. and Mavric, M.

2013 "Postcards Mobility: going beyond image and text". Annals of Tourism Research. 40(1): 18-39

Araujo Perazzolo, Capellano Dos Santos, M. \& Pereira, S.

2013 "O Acolhimiento - ou hospitalidade turística - como interface possível entre o universal e o local no contexto da mundalizacao". Pasos Revista de Turismo y Patrimonio Cultural. 11(1): 45-55

Aries, P.

2011 El Hombre ante la muerte. Buenos Aires: Taurus.

Baker, W.

1998 Down the Tube. New York: Basic Books

Baloglu, S. McClearly, K. w.

1999 "A Model of Destination Image". Annals of Tourism Research. 26(4): 868-897.

Baudrillard, J.

1998 Simulacra \& Simulation. (The body in theory: histories of cultural Materialism. J. Baudrillard edited by Mark Poster. California: Stanford University Press. pp. 166-184

Baudrillard, J.

2002 Cool Memories IV. New York: Verso.

Belting, $\mathrm{H}$.

2007 Antropología de la Image. Buenos Aires: Katz.

Blumenberg, $\mathrm{H}$.

1993 "Light as a metaphor of truth". Modernity and the Hegemony of Vision. D. M Levin. California: University of California Press, pp. 31-62

Bourdieu, P.

2003 Un Arte Medio. Ensayo sobre los usos sociales de la fotografía. Barcelona: Gustavo Gilli.

Budd, M. Craig, S. \& Stinman C.

1999 Consuming Enviroments. Television and Commercial Culture. New Brunswick: Rutgers University Press.

Carman, J. M.

1990 "Consumer perception of service quality: an assessment of SERVQUAL dimension". Journal of Retailing. 66: 33-35.

Capacci, A.

2003 A modo de introducción: la difícil relación entre turismo y medio ambiente. Genova: Ed. Brigati.
Castrogiovanni, C. A.

2007 "Lugar, no-lugar y entre-lugar: los ángulos del espacio turístico". Estudios y Perspectivas en Turismo. 16(1): 5-25.

Celma Rovira, A. y DuBois, Bernard.

1999 Comportamiento del Consumidor. Madrid: Editorial Prentice-Hall.

Cordero Ulate. A.

2006 Nuevos Ejes de Acumulación y Naturaleza. El caso del turismo. Buenos Aires: CLACSO.

Crompton, J.

1979 "Motivation for pleasure vacations". Annals of Tourism Research. 6(4): 408-424.

Dinica, V.

2009 "Governance for sustainable Tourism: a comparison of international and Dutch visions". Journal of Sustainable Tourism. 17(5): 583-603.

Eyenga, I. I et al.

2009 "Photodegeneration, a solution for the shopping bad visual pollution problems?". Macromolecular Simposia. 178(1): 139-152

Farrell, B. and Runyan, D.

1991 "Ecology and tourism". Annals of tourism Research. 18(1): 26-40

Fernandez Fuster, L.

1985 Introducción a la Teoría y técnica del turismo. Madrid: Alianza Editorial.

Flad, H.

1997 "Country Clutter. Visual Pollution and the rural Roadscape". Annals of American Academy of Political Social Science. 553.

Fornell, C.

1992 "A National Customer satisfaction barometer. The Swedish experience". Journal of Marketing. 56: 6-21

Gazerra, A. y Lombardo, L.

2007 "Calidad percibida en empresas de transporte Aéreo". Estudios y Perspectivas en Turismo. 16(3): 361-372

George, B, Inbakaran, R. y Poyyamoli, G.

2010 "To Travel or Not to travel: towards understanding the theory of nativistic motivation". Tourism, an international interdisciplinary Journal. 58(4): 395-407.

Hall, Edward.

1958 The Silent Lenguage. New York: Doubleday.

Jafari, J.

2005 "The Scientifization of Tourism". In Valene Smith and Maryann Brent (eds). Host and Guest revisited: tourism issues of the 21th century. New York: Cognizant Communications. 28-41 
Jollife, L.

2005 "Tourism and Development in Tropical

Islands: political ecology Perspectives". Annals of tourism Research. 32(1): 284-286.

Kant, I.

2004 The Critique of Pure Reason. Buenos Aires: Libertador.

Kant, I

2007 On the beautiful and the sublime. Buenos Aires: Libertador.

Khatchikian, M.

2000 Historia del Turismo. Lima: Universidad San Martín de Porres.

Kotler, P; Haider, D y Rein, J.

1994 Mercadotecnia de Localidades. México: Editorial Diana.

Korstanje, M.

2012 "Maccannell revisited. A critical approach to structuralism." Enlightening Tourism. A pathmaking journal. 2(2): 116-142.

Korstanje, M. and Olsen, D.

2012 "The discourse of risk in horror movies post 9/11: hospitality and hostility in perspective". International Journal of Tourism Anthropology. 1(3-4): 304-317.

Maccannell, D.

2003 The tourist, a new theory of leisure class. Barcelona: Ed. Melusina.

Maccannell, D.

2007 Empty Meeting Grounds. Barcelona: Ed. Melusina

Mansfield, C.

2008 Traversing Paris: French Travel writting practices in the late twentieth Century. Saarsbrucken, VDM Verlag.

Mansfield, C. Korstanje, M. and Busby, G.

2011 "Literary Fiction and the imaginary of urban destination". Journal of Tourism Consumption and Practice. 3(2): 20-37

Marcuse, $\mathrm{H}$.

1964 One Dimensional Man. Studies in the ideology of advanced industrial societies. Boston, Beacon Press.

Marzo, Juan Carlos y otros

2002 "La satisfacción del usuario desde el modelo de la confirmación de expectativas: respuesta a algunos interrogantes". Revista Psycothema. 14(4): 765-770. Material disponible en www. psichothema.com

Mead, G. H.

1999 Mind, Self and Society. Barcelona: Paidos.

Merleau-Ponty, M.

1964 Sense and Non-sense. Illinois: Northwestern University Press.
Molina, S. and Agueda, E.

2006 "Tourism Brochures: usefulness images".

Annals of Tourism Research. 33(4): 1036-1056

Moraes Gomes de, Adriana

2007 "Análisis de las acciones promocionales de

los hoteles para reducir la estacionalidad".

Estudios y Perspectivas en Turismo. 16(3): 303-322.

Nadeau, J. et al.

2008 "Destination in a country image context". Annals of tourism Research. 35(1): 84-106.

Nisbett, R. y Kanousse, D.

1969 "Food deprivation and supermarket Shopping Behaviour". Journal of Personality and Social Psychology. 289-294.

Noelle-Neumann, E.

1995 La Espiral del Silencio: opinión pública.

Nuestra piel social. Buenos Aires: Editorial

Paidos

Leiper, N.

1979 "The Framework of tourism". Annals of

Tourism Research. 6(4): 390-407.

Levin, D. M.

1993 "Decline and Fall: oculacentrism in Heidegger's reading of the history of methapysic". Modernity and the Hegemony of Vision. D. M Levin. California: University of California Press, pp. 186-127.

O'Connor, N. Flanagan, S. and Gilbert, D.

2010 "The Capitalizing of film induced tourism phenomenon through stakeholder collaboration in Yorkshire, UK". E-RTR, e review of Tourism Research. 8(1): 1-11.

Palhares, G.

2002 Transportes Turísticos. San Pablo: Aleph Editorial.

Parasuraman, A. Zaithaml, V y Berry, L.

1988 "A conceptual model of service quality and its implictions for future research". Journal of Marketing. 49: 41-50.

Pastoriza, E.

2011 La Conquista de las Vacaciones: breve historia del turismo en la Argentina. Buenos Aires: Edhasa.

Pearce, D.

2003 Geografía del Turismo: flujos y regiones en el mercado de viajes. San Pablo: Editorial Aleph.

Peters, K.

2011 "Negotiating the Place and Placement of banal tourist souvenir in the home". Tourism Geographies. 13(2): 234-256 
Quinn, B.

2009 "Problematising Festival Tourism. Arts festival and sustainable tourism in Ireland". Journal of Sustainable Tourism. 14(3): 288$-306$.

Roberts, S. and Tribe, J.

2008 "Sustainablity indicators for Small tourism enterprises - an exploratory perspective". Journal of Sustainable Tourism. 16(5): 575$-594$.

Royce, J.

1983 The Spirit of Modern Philosophy. New York: Dover Publications.

Ryan, C. Huiman, G. and Chon, K.

2010 "Tourism to polluted lakes : issues for tourists and the industry, an empirical analysis of four Chinese lakes". Journal of Sustainable Tourism. 18(5): 595-614.

Ryle, G.

1949 The Concept of mind. Middlesex: Penguin Books.

Sampaio-Cioce, A. C et al.

2007 "Acuerdo productivo local de base comunitaria y ecodesarrollo: análisis de tres experiencias brasileñas". Estudios y Perspectivas en Turismo. 16(2): 216-233.

Spreng, R y Mckoy R.

1996 "An empirical examination of a model of perceived service of quality and satisfaction." Journal of Retailing. 72(2): 201-215.

Swarbrooke, J.

2000 Turismo Sustentable. San Pablo, el Aleph.

Tamagni, L.; Lombardo, L; Gazerra, M.

2000 "Gestión de la calidad en empresas de servicios turísticos. Facultad de Turismo, Universidad Nacional del Comahue, Argentina.

Troncoso, C y Lois, C.

2004 "Políticas turísticas y Peronismo: Los atractivos turísticos promocionados en visión de Argentina (1950)". Pasos: revista de turismo y patrimonio cultural. 2(2): 281-294.

Ulmer, G.

1994 Heuretics, the logic of invention. Baltimore: John Hopkins University.

Urry, J. and Larsen, J.

2012 The Tourist Gaze 3.0. London: Sage.

Virilio, P.

2007 Ciudad Pánico: el afuera comienza aquí. Buenos Aires: Libros el Zorzal

Virilio, P.

1996 El Arte del Motor: aceleración y realidad.

Buenos Aires: El Manantial.

Woodside, A. and Dubelaar, C.

2002 "A general theory of tourism consumption systems. A conceptual framework and an empirical exploration". Journal of Travel Research. 41(2): 120-132.
Zuloaga, C. P.

2006 "Una Mirada al paisaje como recurso turístico". Revista Interamericana de Paisaje y Turismo. 2(2): 76-82.
Recibido:

$01 / 03 / 2013$

Reenviado:

$01 / 05 / 2013$

Aceptado:

$01 / 07 / 2013$

Sometido a evaluación por pares anónimos 